\title{
Clinical and neurophysiological description of patients with POEMS syndrome
}

\author{
Luis Lee-Chen, Ricardo Williams-de-Roux, Erwin Chiquete, * José Jesús Aceves-Buendía, \\ Eduardo Ruiz-Ruiz, Jennefer Portillo-Valle, Tatiana Bliskunova, Elizabeth Rodríguez-Perea, \\ Liz Toapanta-Yanchapaxi, Guillermo García-Ramos, Carlos Cantú-Brito and Bruno Estañol \\ Neurology and Psychiatry Department, Instituto Nacional de Ciencias Médicas y Nutrición Salvador Zubirán, Mexico City, Mexico
}

\begin{abstract}
Introduction: POEMS syndrome (polyneuropathy, organomegaly, endocrinopathy, monoclonal protein, skin changes) is a monoclonal gammopathy with polyneuropathy as a mandatory criterion. Objective: To describe potential associations between clinical expression and electrodiagnostic patterns in POEMS syndrome. Method: Observational, retrospective, cross-sectional study of cases cared for in a referral center, diagnosed with POEMS syndrome from 2009 to 2019. Results: Eleven patients (8 men) were analyzed. Median age at diagnosis was 40 years (range: 31-51; mean: $37.19 \pm$ 15.67 years). Mean latency at diagnosis was $9.7 \pm 8.37$ months. In all subjects, initial clinical manifestation was polyneuropathy. Most patients had an axonal pattern $(n=5)$, followed by demyelinating $(n=4)$ and mixed patterns $(n=2)$. Monoclonal gammopathy was observed in all (6 $\lambda$ and $5 \kappa$ cases; immunoglobulin [Ig] G: 72 \%; IgA: 18 \%; IgM: $9 \%$ ). Medical Research Council sum score was lower in the axonal pattern (median: 37.00 vs. 45.5; $p=0.024$ ). There were no differences in systemic involvement between electrophysiological patterns. Conclusion: Electrophysiological patterns are unlikely to have a clear extra-neurological clinical correspondence; however, this will have to be definitively proven with a larger sample size.
\end{abstract}

KEY WORDS: Axonal. Demyelinating. POEMS. Polyneuropathy. Syndrome.

\section{Descripción clínica y neurofisiológica de pacientes con el síndrome POEMS}

\section{Resumen}

Introducción: El síndrome POEMS (polyneuropathy, organomegaly, endocrinopathy, monoclonal protein, skin changes) es una gammapatía monoclonal con polineuropatía como criterio obligatorio. Objetivo: Describir las potenciales asociaciones entre la expresión clínica y los patrones de electrodiagnóstico en el síndrome POEMS. Método: Estudio observacional, retrospectivo y transversal de los casos atendidos en un centro de referencia con diagnóstico de síndrome de POEMS de 2009 a 2019. Resultados: Se analizó a 11 pacientes (8 hombres). La mediana de la edad al diagnóstico fue de 40 años (rango: 31-51, media: $37.19 \pm 15.67$ años). La latencia media al diagnóstico fue de $9.7 \pm 8.37$ meses. En todos la manifestación clínica inicial fue la polineuropatía. La mayoría de los pacientes presentaron un patrón axonal $(n=5)$, seguido del desmielinizante $(n=4)$ y mixto $(n=2)$. La gammapatía monoclonal se observó en todos (6 casos $\lambda$ y $5 \mathrm{\kappa}$, inmunoglobulina [lg] G: 72\%, IgA: 18\%, IgM: 9\%). El Medical Research Council sum score fue menor en el patrón axonal (medianas: 37.00 vs. 45.5, $p=0.024)$. No se presentaron diferencias en la afección sistémica entre patrones electrofisiológicos. Conclusión: Es poco

Correspondence:

*Erwin Chiquete

E-mail: erwin.chiquetea@incmnsz.mx
Gac Med Mex. 2021;157:466-472

Contents available at PubMed

www.gacetamedicademexico.com

0016-3813/@ 2021 Academia Nacional de Medicina de México, A.C.. Published by Permanyer. This is an open access article under the CC BY-NC-ND license (http://creativecommons.org/licenses/by-nc-nd/4.0/). 
probable que los patrones electrofisiológicos tengan una correspondencia clínica extraneurológica clara, sin embargo, esto deberá probarse de forma definitiva con un mayor tamaño de muestra.

PALABRAS CLAVE: Axonal. Desmielinizante. POEMS. Polineuropatía. Síndrome.

\section{Introduction}

POEMS syndrome, or Crow-Fukase disease, is a plasma cell disorder with systemic involvement, the acronym of which describes the characteristics of the syndrome: polyneuropathy, organomegaly, endocrinopathy, monoclonal protein and skin changes, although not all affected systems are related to the acronym., ${ }^{1,2}$ There is no specific diagnostic test, with the presence of three major criteria being required: polyneuropathy, eminently $\lambda$ monoclonal gammopathy, bone lesions, vascular endothelial growth factor (VEGF) elevation and/or Castleman disease, with at least one of six minor criteria $^{3}$ (Table 1). There is a slight predominance in men, with a ratio of 1.4:1, with median age at diagnosis of between 45 and 50 years, depending on the series. ${ }^{4-6}$ Prevalence is estimated to be approximately 0.3 per 100,000 population. ${ }^{7,8}$ Since it is a rare disease, it is rarely included in demyelinating neuropathy differential diagnosis, which leads to diagnostic and treatment errors. ${ }^{9}$

Neuropathy is usually one of the initial manifestations, which occurs with sensorimotor involvement, predominantly distal and symmetrical, but that can affect all four extremities. ${ }^{10,11}$ Electrophysiologically, neuropathy is predominantly demyelinating, particularly in intermediate rather than distal segments, with subsequent axonal damage, predominantly distal, both in motor and sensory nerves. ${ }^{11,12} \mathrm{~A}$ mixed pattern of involvement is likely to be found at the time of diagnosis. ${ }^{13}$

POEMS is a treatable entity, and it can be prevented from progressing to ambulation loss in $75 \%$ of cases with timely treatment. ${ }^{14,15}$ VEGF has a good diagnostic performance in POEMS syndrome, in addition to being a guide for assessing treatment response. Unlike what occurs in other chronic degenerative neuropathies, ${ }^{16,17}$ with the exception of VEGF, imaging or laboratory characteristics play a much lesser role in clinical monitoring of evolution and treatment response,,$^{1,2,15}$ and although electrophysiological characteristics could probably fulfill this role, this requires further clinical evidence. ${ }^{11,13}$

Clinical research on POEMS syndrome neuropathy is also limited..$^{11-19}$ It has focused on characterizing its clinical, paraclinical and, to a lesser extent,
Table 1. POEMS syndrome diagnostic criteria 2019 update

\begin{tabular}{|c|c|}
\hline $\begin{array}{l}\text { Diagnostic } \\
\text { category }\end{array}$ & Criteria \\
\hline \multirow{2}{*}{$\begin{array}{l}\text { Mandatory major } \\
\text { criteria } \\
\text { (both required) }\end{array}$} & 1. Polyneuropathy \\
\hline & $\begin{array}{l}\text { 2. Monoclonal plasma cell-proliferative } \\
\text { disorder (mostly } \lambda \text { ) }\end{array}$ \\
\hline \multirow{3}{*}{$\begin{array}{l}\text { Other major criteria } \\
\text { (one required) }\end{array}$} & 3. Castleman disease \\
\hline & 4. Sclerotic bone lesions \\
\hline & 5. VEGF elevation \\
\hline \multirow[t]{6}{*}{$\begin{array}{l}\text { Minor criteria } \\
\text { (one required) }\end{array}$} & $\begin{array}{l}\text { 6. Organomegaly (splenomegaly, } \\
\text { hepatomegaly or lymphadenopathy) }\end{array}$ \\
\hline & $\begin{array}{l}\text { 7. Extravascular volume overload (edema, } \\
\text { pleural effusion, ascites) }\end{array}$ \\
\hline & $\begin{array}{l}\text { 8. Endocrinopathy (adrenal, thyroid, pituitary, } \\
\text { gonadal, parathyroid, pancreatic) }\end{array}$ \\
\hline & $\begin{array}{l}\text { 9. Skin changes (hyperpigmentation, } \\
\text { hypertrichosis, glomeruloid } \\
\text { hemangiomata, plethora, acrocyanosis, } \\
\text { flushing, white nails) }\end{array}$ \\
\hline & 10. Papilledema \\
\hline & 11. Thrombocytosis/polycythemia \\
\hline \multirow{7}{*}{$\begin{array}{l}\text { Other signs and } \\
\text { symptoms }\end{array}$} & Clubbing \\
\hline & Weight loss \\
\hline & Hyperhidrosis \\
\hline & $\begin{array}{l}\text { Pulmonary hypertension/restrictive lung } \\
\text { disease }\end{array}$ \\
\hline & Thrombotic diatheses \\
\hline & Diarrhea \\
\hline & Low cyanocobalamin (vitamin $B_{12}$ ) levels \\
\hline
\end{tabular}

POEMS: polyneuropathy, organomegaly, endocrinopathy, monoclonal protein, skin changes; VEGF: vascular endothelial growth factor.

Adapted from Nakanishi et al., 1984.4

electrophysiological presentation. There are only few studies that focus on evaluating the potential association between POEMS syndrome clinical presentation and electrophysiological pattern (e.g., demyelinating vs. axonal pattern). ${ }^{12,13}$ Therefore, we set out to perform an analysis on the electrophysiological pattern and its correspondence with clinical presentation of a series of patients with POEMS syndrome in order to compare it with similar previous literature. 


\section{Method}

In this retrospective, observational study, we present a detailed description of patients who seek medical attention at the Neurology Department and the Neuromuscular Diseases Clinic of "Salvador Zubirán" National Institute of Medical Sciences and Nutrition, in Mexico City. The study was approved by the research committee and by the research ethics committee of the Institute, with a signed informed consent document not being required, given that it was a retrospective study.

All medical records with a documented diagnosis of POEMS syndrome treated at the Institute within the 2009-2019 period were included in an electronic database designed for the collection of clinical, laboratory, imaging and electrophysiological information. Cases with missing information or in diagnostic process but not yet completed, or those in whom electrodiagnostic studies were carried out with a difference of more than six months with regard to POEMS syndrome final diagnosis were excluded. In those patients with more than one electrodiagnostic study, the one closest to the date of POEMS final diagnosis establishment was recorded and analyzed. The requirement of a recent electrodiagnostic study at the time of POEMS diagnosis establishment complies with the general goal of evaluating the association of clinical and electrophysiological presentation of the syndrome, in order to distinguish potential differences between the demyelinating and the axonal pattern. In addition, cases in which POEMS syndrome diagnostic criteria were not fully met were discarded, as described in current clinical guidelines, ${ }^{3,10,20}$ as well as cases in which neuropathy had another explanation, such as diabetes mellitus, alcoholism or use of chemotherapy, among other etiologies. Although in exceptional cases polyneuropathy may precede the POEMS diagnosis by many years, ${ }^{17,18}$ cases in which polyneuropathy preceded the POEMS diagnosis for $\geq$ 3 years were finally also excluded in order for other differential diagnoses, which might confuse the electrodiagnostic evaluation results in a small sample, to be excluded with higher accuracy.

For data collection, all medical records with POEMS syndrome diagnoses were requested from the medical informatics department. The records were then reviewed in order to rule out those that did not meet the selection criteria. The data of the selected records were reviewed exclusively by the author of the work, who used a data capture sheet to extract the information required for the study. In the collection forms, a coding method was used that was only known by the author, to protect their confidentiality.

The Medical Research Council (MRC) sum score was used as a quantitative variable that expresses the severity of motor involvement, in which 0 expresses the worst state (complete paralysis) and 60 points the best (normal strength, or $5 / 5$ in all evaluated segments). The MRC sum score was compared between axonal, demyelinating and mixed electrophysiological patterns.

All statistical operations were carried out with the SPSS data analysis software, version 20.0 for iOS (IBM Inc., USA). With the collected information, data were then presented using tables, and the results were analyzed with central tendency measures. Demographic data were presented as simple relative frequencies in the form of percentages. Continuous quantitative variables with normal distribution were analyzed as means and standard deviation, while those with non-parametric distribution were presented as medians with minimum and maximum limits, or with interquartile ranges, as appropriate. To contrast the primary hypothesis, tests were used to compare means for two or more groups, as follows: for quantitative variables with normal distribution between two groups, Student's t test was used; one-way ANOVA was used for quantitative variables with normal distribution between more than two groups. Mann-Whitney's U-test was used to compare medians for non-parametric continuous variables between two groups, and Kruskal-Wallis test was used when more than two groups were compared. All analyses were bilateral and were considered significant when $p$-value was $<0.05$. The tables that are constructed with the data analyses are contrasted with the three largest publications that present clinical and electrophysiological information in a manner that is comparable to that in the present study, although these publications do not represent the only or the largest case series. ${ }^{5,11-16}$

\section{Results}

Initially, 33 medical records of patients diagnosed with polyneuropathy associated with monoclonal gammopathy were obtained for review. After excluding 12 records, either due to incomplete data or diagnostic approaches in progress $(n=4)$, for reporting a diagnosis other than POEMS ( $n=3)$, for describing other causes for peripheral nerve damage in addition 
to POEMS diagnosis $(n=3)$ or due to the existence of a neuropathy that preceded the POEMS diagnosis by more than three years $(n=2), 11$ patients ( 8 males) were finally analyzed for potential clinical-electrophysiological association (Table 2). Median age at diagnosis was 40 years (range: $31-51$, mean: $37.19 \pm$ 15.67 years). Median age at symptom onset was 38 years (range: $32-51$, mean: $38.0 \pm 16.19$ years). Thus, average time between the onset of clinical manifestations and POEMS diagnosis was $9.7 \pm$ 8.37 months. In the 11 cases, initial clinical manifestation was polyneuropathy. Most patients had an axonal pattern $(n=5)$, followed by demyelinating $(n=$ 4 ) and mixed patterns $(n=2)$. Owing to our selection criteria, plasma cell dyscrasia was observed in all 11 patients ( 6 cases with $\lambda$ and 5 with $\kappa$ gammopathy; immunoglobulin [Ig] G: $72 \%, \lg A: 18 \%, \operatorname{lgM}: 9 \%)$, organomegaly in 8 , endocrinopathy in 6 , skin changes in 8 , volume overload in 8 , bone lesions in 7 , papilledema in 3 and pulmonary hypertension in 2 cases.

All 11 analyzed patients had chronic weakness of distal and ascending onset in the lower limbs at the time of diagnosis, with toe walking of variable degrees. At diagnosis, 5 patients also had distal upper limb weakness. However, sensory alterations preceded motor alterations in 6 cases ( 3 with positive alterations and 3 with negative sensory alterations). Lower limbs areflexia was found in all 11 analyzed patients, with upper limbs hyporeflexia in 7 cases and normoreflexia in 4. MRC sum score was lower among the patients with axonal pattern (median: 37.00, range: 21-39; mean: $31.40 \pm 8.65$ years), in comparison with the demyelinating group (median: 49.5, range: 44-52; mean: $48.75 \pm 3.95$ years) or the mixed group (median: 36.00 , range: $34-38$; mean: $36.00 \pm 2.82$ years). Median MRC sum score was significantly lower in the group of patients with axonal pattern in comparison with the rest (37.00, range: $21-39$ vs. 45.5 , range: $34-$ 52 , respectively; $p=0.024$ ).

Motor amplitude was not evoked in the stimuli of 22 motor nerves, all of lower limbs, and it was found to be decreased in $59 \%$ of the remaining amplitudes that were analyzed (Table 3). Nerve conduction velocity was found without response in 34 of occasions, decreased by $79 \%$ of normal velocity, with similar distribution between upper and lower limbs, within a range of $22-100 \mathrm{~m} / \mathrm{s}$, with a mean slowing-down percentage of $93 \%$. Motor latencies were more severely prolonged in ulnar nerves than in median motor nerves and more affected in tibial than in fibular nerves. Interestingly, latencies were found to be more prolonged in upper than in lower limbs. No conduction blocks were found.

Average amplitudes of upper limbs sensory nerves was normal, although at the level of the sural nerve, an average decrease of $52 \%$ in amplitude was found. Sensory nerve conduction velocity had a larger decrease in upper than in lower limbs, with an average of $83 \%$ with regard to normal values, with no difference between median and ulnar nerves. Sensory nerves latency was prolonged in $225 \%$ on average, with greater alteration in lower than in upper limbs.

Average time between symptom onset and POEMS diagnosis was different between demyelinating (16.29 \pm 13.04 months), axonal (10.53 \pm 4.92 months) and mixed patterns $(8.0 \pm 4.24$ months) $(p=0.45)$. No statistically significant differences were found between the demyelinating and axonal/mixed patterns (16.29 vs. 9.81, respectively; $p=0.21$ ), or between the axonal and demyelinating/mixed patterns (10.53 vs. 13.52 , respectively; $p=0.21$ ). Neither were statistically significant differences found in the average number of diagnostic criteria that were met (major, minor and associated/others) between axonal (11.6), demyelinating (17.25) or mixed patterns (14.0) $(p=0.27)$.

\section{Discussion}

In this study, we found characteristics that were very similar to those reported in other studies, including multicenter series with larger numbers of patients. ${ }^{5,7,8,11-16}$ However, with the limitations of a small sample size, we did not find that the electrophysiological patterns differed in latency time between the onset of clinical manifestations and POEMS syndrome final diagnosis, or in the burden of diagnostic criteria or clinical manifestations of the syndrome. This is opposed to our initial working hypothesis, since we expected that patients with an axonal electrophysiological pattern would have a longer latency between the onset of symptoms and diagnosis and, consequently, a larger number of criteria that were met. This suggests that, although patients with POEMS syndrome and axonal damage have higher motor disability, this is not dependent on the time with the disease or on the severity of systemic involvement. Although this finding may be counterintuitive, clinical presentation severity has previously been suggested to probably be more linked to disease activity (which is not homogeneous among patients) rather than to time with the disease or magnitude of markers such as serum VEGF or cytokine concentrations. ${ }^{19,20}$ 
Gaceta Médica de México. 2021;157

Table 2. Characteristics of patients with POEMS syndrome

\begin{tabular}{|c|c|c|c|c|}
\hline Clinical characteristics & $\begin{array}{l}\text { Current study } \\
\qquad(n=11)\end{array}$ & $\begin{array}{l}\text { Nakanishi et al., } 1984^{4} \\
(n=102)\end{array}$ & $\begin{array}{l}\text { Dispenzieri et al., } 2003^{5} \\
\text { ( } \mathrm{n}=99)\end{array}$ & $\begin{array}{l}\text { Li et al., } 2011^{6} \\
\qquad(n=99)\end{array}$ \\
\hline Median age in years (IQR) at diagnosis & 43 & 46 & 51 & 45 \\
\hline Male gender & $9(81)$ & $67(67)$ & $62(62)$ & $58(58)$ \\
\hline Polyneuropathy, n (\%) & $11(100)$ & $102(100)$ & $99(100)$ & $98(99)$ \\
\hline Axonal & $5(45)$ & - & - & - \\
\hline Demyelinating & $4(36)$ & - & - & - \\
\hline Mixed & $2(18)$ & - & - & - \\
\hline Organomegaly, n (\%) & $8(72)$ & - & $50(50)$ & $85(86)$ \\
\hline Hepatomegaly & $3(27)$ & $80(82)$ & $24(24)$ & $47(47)$ \\
\hline Splenomegaly & $3(27)$ & $36(39)$ & $22(22)$ & $70(71)$ \\
\hline Lymphadenopathy & $7(63)$ & $62(65)$ & $26(26)$ & $74(75)$ \\
\hline Castleman disease & $3(27)$ & $19(63)$ & $11(73)$ & $24(24)$ \\
\hline Endocrinopathy, n (\%) & $11(100)$ & - & - & - \\
\hline Gonadal axis & $6(54)$ & - & - & - \\
\hline Adrenal axis & $1(9)$ & - & - & - \\
\hline Increased prolactin & $3(27)$ & - & - & - \\
\hline Gynecomastia or galactorrhea & 0 & - & - & - \\
\hline Diabetes mellitus & $3(27)$ & - & - & - \\
\hline Hypothyroidism & $6(54)$ & - & $14(14)$ & $42(42)$ \\
\hline Monoclonal peak, n (\%) & $11(100)$ & - & $99(100)$ & $99(100)$ \\
\hline $\lg A-\lambda$ & $1(9)$ & $29(41)$ & $44(52)$ & $65(71)$ \\
\hline $\lg G-\lambda$ & $5(45)$ & $38(54)$ & $40(48)$ & $20(22)$ \\
\hline $\lg M-\lambda$ & 0 & 0 & $1(1)$ & 0 \\
\hline $\lg A-\kappa$ & $1(9)$ & $3(4)$ & 0 & $1(1)$ \\
\hline $\lg G-\kappa$ & $3(27)$ & $1(1)$ & 0 & $2(2)$ \\
\hline $\operatorname{lgM}-\kappa$ & $1(9)$ & 0 & 0 & 0 \\
\hline Skin changes, n (\%) & $8(72)$ & - & $67(68)$ & $87(88)$ \\
\hline Hyperpigmentation & $2(9)$ & - & - & - \\
\hline Acrocyanosis and plethora & 0 & - & - & - \\
\hline Hemangioma/telangiectasia & $3(27)$ & - & - & - \\
\hline Hypertrichosis & $1(9)$ & - & - & - \\
\hline Thickening & $2(18)$ & - & - & - \\
\hline Other, n (\%) & $11(100)$ & - & - & - \\
\hline Papilledema & $3(27)$ & $56(62)$ & $29(29)$ & $56(64)$ \\
\hline Volume overload & $8(72)$ & - & $29(29)$ & $87(88)$ \\
\hline Peripheral edema & $5(45)$ & $91(91)$ & $24(24)$ & $84(85)$ \\
\hline Ascites & $5(45)$ & $53(62)$ & $7(7)$ & $54(55)$ \\
\hline Pleural effusion & $6(54)$ & $36(40)$ & $3(3)$ & $43(43)$ \\
\hline Bone lesions & $7(63)$ & $27(27)$ & $56(50)$ & $7(63)$ \\
\hline Osteosclerotic & $5(45)$ & $19(19)$ & $31(55)$ & $5(45)$ \\
\hline Lytic & 0 & $8(8)$ & $8(14)$ & - \\
\hline Mixed & $2(18)$ & 0 & $17(30)$ & $2(18)$ \\
\hline Pulmonary hypertension* & $2(18)$ & - & $5(5)$ & $36(36)$ \\
\hline Thrombocytosis $^{\dagger}$ & $1(9)$ & - & $53(54)$ & $54(55)$ \\
\hline Polycythemia $^{\ddagger}$ & $1(9)$ & - & $18(18)$ & $9(9)$ \\
\hline
\end{tabular}


Table 3. Comparison of neurophysiological characteristics of patients with POEMS syndrome $n=11$

\begin{tabular}{|c|c|c|c|c|c|c|}
\hline \multirow[t]{2}{*}{ Electrophysiological characteristics } & \multicolumn{3}{|c|}{ Current study } & \multicolumn{3}{|c|}{ Ju-Hong et al., 2055'13 } \\
\hline & $n$ & Distal mean \pm SD & Mean \pm SD $(\%)$ & $n$ & Distal mean \pm SD & Mean \pm SD $(\%)$ \\
\hline $\begin{array}{l}\text { Motor latency (ms) } \\
\text { Median } \\
\text { Ulnar } \\
\text { Tibial } \\
\text { Fibular }\end{array}$ & $\begin{array}{l}20 \\
22 \\
12 \\
10\end{array}$ & $\begin{array}{l}4.62 \pm 1.18 \\
5.30 \pm 4.50 \\
4.45 \pm 2.10 \\
4.28 \pm 0.79\end{array}$ & $\begin{array}{c}121.44 \pm 31 \\
139.47 \pm 118.40 \\
94.70 \pm 44.70 \\
91.10 \pm 16.80\end{array}$ & $\begin{array}{c}12 \\
12 \\
6 \\
10\end{array}$ & $\begin{array}{l}5.1 \pm 1.24 \\
3.73 \pm 1.11 \\
6.78 \pm 3.29 \\
4.99 \pm 1.06\end{array}$ & $\begin{array}{l}146.97 \pm 35.66 \\
141.41 \pm 42.13 \\
126.55 \pm 61.43 \\
101.84 \pm 21.60\end{array}$ \\
\hline $\begin{array}{l}\text { Motor NCV }(\mathrm{m} / \mathrm{s}) \\
\text { Median } \\
\text { Ulnar } \\
\text { Tibial } \\
\text { Fibular }\end{array}$ & $\begin{array}{l}20 \\
22 \\
12 \\
10\end{array}$ & $\begin{array}{c}40.55 \pm 9.50 \\
42.50 \pm 14.90 \\
37.20 \pm 5.90 \\
49.40 \pm 20.7\end{array}$ & $\begin{array}{c}82.60 \pm 19.30 \\
86.70 \pm 30.00 \\
84.60 \pm 13.40 \\
120.40 \pm 50.50\end{array}$ & $\begin{array}{c}12 \\
12 \\
6 \\
10\end{array}$ & $\begin{array}{c}32.82 \pm 8.97 \\
32.84 \pm 10.52 \\
29.63 \pm 11.71 \\
29.49 \pm 8.49\end{array}$ & $\begin{array}{l}60.63 \pm 16.57 \\
61.07 \pm 19.57 \\
78.42 \pm 30.98 \\
67.97 \pm 19.56\end{array}$ \\
\hline $\begin{array}{l}\text { CMAP }(m V) \\
\text { Median } \\
\text { Ulnar } \\
\text { Tibial } \\
\text { Fibular }\end{array}$ & $\begin{array}{l}22 \\
22 \\
12 \\
10\end{array}$ & $\begin{array}{l}4.40 \pm 1.87 \\
4.70 \pm 2.80 \\
5.10 \pm 2.70 \\
3.52 \pm 0.71\end{array}$ & $\begin{array}{l}- \\
- \\
- \\
-\end{array}$ & $\begin{array}{c}12 \\
12 \\
6 \\
10\end{array}$ & $\begin{array}{c}5.84 \pm 3.74 \\
6.68 \pm 3.1 \\
5.18 \pm 6.54 \\
1.38 \pm 1.97\end{array}$ & $\begin{array}{l}- \\
- \\
- \\
-\end{array}$ \\
\hline $\begin{array}{l}\text { SNAP }(m V) \\
\text { Median } \\
\text { Ulnar } \\
\text { Sural }\end{array}$ & $\begin{array}{l}21 \\
20 \\
10\end{array}$ & $\begin{array}{c}15.09 \pm 11.56 \\
16.65 \pm 9.65 \\
6.80 \pm 3.98\end{array}$ & $\begin{array}{l}- \\
- \\
-\end{array}$ & $\begin{array}{l}8 \\
9 \\
8\end{array}$ & $\begin{array}{c}9.9 \pm 6.31 \\
10.29 \pm 2.81 \\
9.69 \pm 6.8\end{array}$ & $\begin{array}{l}- \\
- \\
-\end{array}$ \\
\hline $\begin{array}{l}\text { Sensory NCV (m/s) } \\
\text { Median } \\
\text { Ulnar } \\
\text { Sural }\end{array}$ & $\begin{array}{l}21 \\
20 \\
12\end{array}$ & $\begin{array}{c}39.09 \pm 9.77 \\
39.35 \pm 11.57 \\
38.70 \pm 13.90\end{array}$ & $\begin{array}{l}78.18 \pm 19.55 \\
78.70 \pm 23.14 \\
94.39 \pm 34.87\end{array}$ & $\begin{array}{l}8 \\
9 \\
8\end{array}$ & $\begin{array}{l}34.83 \pm 5.09 \\
33.93 \pm 5.05 \\
32.09 \pm 3.39\end{array}$ & $\begin{array}{c}98.82 \pm 14.45 \\
87.57 \pm 13.03 \\
93.52 \pm 9.89\end{array}$ \\
\hline $\begin{array}{l}\text { Sensory latency (ms) } \\
\text { Median } \\
\text { Ulnar } \\
\text { Sural }\end{array}$ & $\begin{array}{l}20 \\
20 \\
10\end{array}$ & $\begin{array}{c}7.50 \pm 12.32 \\
5.21 \pm 5.41 \\
7.62 \pm 9.95\end{array}$ & $\begin{array}{l}- \\
- \\
-\end{array}$ & $\begin{array}{l}- \\
- \\
-\end{array}$ & $\begin{array}{l}- \\
- \\
-\end{array}$ & $\begin{array}{l}- \\
- \\
-\end{array}$ \\
\hline
\end{tabular}

In contrast to the study by Ju-Hong et al., ${ }^{13}$ greater prolongation of latencies and a decrease in velocities were found in all four extremities, as well as a larger decrease in motor amplitudes, which is consistent with the axonal and mixed pattern, the prevalence of which was slightly higher than expected in our study. Latency prolongation was longer in ulnar than in median nerves and longer in tibial than in fibular nerves, which differs from how Ju-Hong et al. ${ }^{13}$ report these observations. As it was to be expected, no conduction blocks were found, which are more commonly described in immune-mediated demyelinating polyneuropathies.

In addition to the aforementioned main limitation this study has owing to its small sample size, the retrospective design may imply that some variables of interest have not been collected with the highest accuracy required by the hypothesis and objectives of the present analysis. Neither did we evaluate here the differences that the three electrophysiological patterns could have in response to treatment, or in the concentrations of biomarkers whose importance has been recently highlighted, such as interleukin (IL) 1, IL-6 or tumor necrosis factor alpha, among others. ${ }^{1-3}$ However, we believe that these results may help in the design of larger observational studies that definitively answer whether the electrophysiological pattern depends on the time with the disease or on its activity, in addition to its determinants.

In conclusion, based on current results, we now believe that electrophysiological patterns are unlikely to have a clear clinical extra-neurological correspondence; however, this will have to be definitively proven with a larger, prospective, longitudinal study.

\section{Funding}

The authors of this article declare that there was no sponsor or funding source for the execution of this study. 


\section{Conflict of interests}

The authors of this article declare that they have no conflicts of interest.

\section{Ethical disclosures}

Protection of human and animal subjects. The authors declare that no experiments were performed on humans or animals for this research.

Confidentiality of data. The authors declare that they have followed the protocols of their work center on the publication of patient data.

Right to privacy and informed consent. The authors declare that no patient data appear in this article.

\section{References}

1. Keddie S, Lunn M. POEMS syndrome. Curr Opin Neurol. 2018;31:551-8.

2. Cerri F, Falzone $Y$, Riva N Quattrini A. An update on the diagnosis and management of the polyneuropathy of POEMS syndrome. J Neurol. 2019;266:258-67

3. Dispenzieri A. POEMS syndrome: 2019 Update on diagnosis, risk-stratification, and management. Am J Hematol. 2019:94:812-27.

4. Nakanishi T, Sobue I, Toyokura Y. The Crow-Fukase syndrome: A study of 102 cases in Japan. Neurology. 1984;34:712-20.

5. Dispenzieri A, Kyle RA, Lacy MQ, Rajkumar SV, Therneau TM, Larson DR, et al. POEMS syndrome: definitions and long-term outcome. Blood. 2003; 101:2496-506

6. Li J, Zhou D, Huang Z, Jiao L, Duan M, Zhang W, et al. Clinical characteristics and long-term outcome of patients with POEMS syndrome in China. Ann Hematol. 2011;90:819-26.
7. Suichi T, Misawa S, Beppu M, Takahashi S, Sekiguchi Y, Shibuya K, et al. Prevalence, clinical profiles, and prognosis of POEMS syndrome in Japanese nationwide survey. Neurology. 2019;93:e975-e983.

8. Wang C, Huang XF, Cai QQ, Cao XX, Duan MH, Cai H. Prognostic study for overall survival in patients with newly diagnosed POEMS syndrome. Leukemia. 2017;31:100-6.

9. Michelle L, Mauermann M. The peripheral neuropathies of POEMS syndrome and Castleman disease. Hematol Oncol Clin N Am. 2018;32:153-63.

10. Join Task Force of the EFNS and the PNS. European Federation of Neurological Societies/Peripheral Nerve Society Guideline on management of paraproteinemic demyelinating neuropathies. Report of a join task force of the European Federation of Neurological Societies and the Peripheral Nerve Society. J Periph Nerv Sys. 2006;11:9-19.

11. Liu M, Zou Z, Guan Y, Li J, Zhou D, Cui L. Motor nerve conduction study and muscle strength in newly diagnosed POEMS syndrome. Muscle Nerve. 2015;51:19-23.

12. Mauermann ML, Sorenson EJ, Dispenzieri A, Mandrekar J, Suarez GA, Dyck PJ, et al. Uniform demyelination and more severe axonal loss distinguish POEMS syndrome from CIDP. J Neurol Neurosurg Psychiatry. 2012;83:480-6.

13. Ju-Hong M, Yoon-Ho H, Kwang-Loo L. Electrophysiological features of patients with POEMS syndrome. Clin Neurophysiol. 2005;116:965-8.

14. Singh D, Wadhwa J, Kumar L, Raina V, Agarwal A, Kochupillai V. POEMS syndrome: experience with fourteen cases. Leuk Lymphoma. 2003:44:1749-52.

15. Shi X, Hu S, Yu X, Zhuang Q, Luo M, Jiang Q, et al. Clinicopathologic analysis of POEMS syndrome and related diseases. Clin Lymphoma Myeloma Leuk. 2015;15:e1521.

16. Carmona-Ruiz HA, Rosales-Uvera SG, Ulloa-Córdoba IA, Orihuela-Rodríguez O, Santiago-Cerecedo E, González-Duarte A, et al. Left atrial function and volume by magnetic resonance in patients with hereditary amyloidosis. Rev Invest Clin. 2019;71:387-92.

17. Nguyen VH. POEMS Syndrome diagnosed 10 years after disabling peripheral neuropathy. Case Rep Med. 2011;2011:126209.

18. Plaza C, Arquero T, García-Raso A, Llamas P. Diagnosis of POEMS syndrome in a patient with long-standing neuropathy. Neurologia. 2019;34:272-4.

19. Scarlato M, Previtali SC, Carpo M, Pareyson D, Briani C, Del Bo R, et al. Polyneuropathy in POEMS syndrome: role of angiogenic factors in the pathogenesis. Brain. 2005;128:1911-20.

20. Sung JY, Kuwabara S, Ogawara K, Kanai K, Hattori T. Patterns of nerve conduction abnormalities in POEMS syndrome. Muscle Nerve. 2002;26:189-93. 